Review

\title{
A Systematic Review of Station Location Techniques for Bicycle-Sharing Systems Planning and Operation
}

\author{
Mohammad Sadegh Bahadori $^{1}\left(\mathbb{D}\right.$, Alexandre B. Gonçalves ${ }^{2, *(\mathbb{D})}$ and Filipe Moura $^{2}$ (D) \\ 1 Instituto Superior Técnico (MIT Program), Universidade de Lisboa, Av. Rovisco Pais, \\ 1049-001 Lisboa, Portugal; sadegh.bahadori@tecnico.ulisboa.pt \\ 2 CERIS, Instituto Superior Técnico, Universidade de Lisboa, Av. Rovisco Pais, 1049-001 Lisboa, Portugal; \\ fmoura@tecnico.ulisboa.pt \\ * Correspondence: alexandre.goncalves@tecnico.ulisboa.pt
}

Citation: Bahadori, M.S.; Gonçalves, A.B.; Moura, F. A Systematic Review of Station Location Techniques for Bicycle-Sharing Systems Planning and Operation. ISPRS Int. J. Geo-Inf. 2021, 10, 554. https://doi.org/ $10.3390 /$ ijgi10080554

Academic Editors: Giuseppe Borruso and Wolfgang Kainz

Received: 30 June 2021

Accepted: 15 August 2021

Published: 17 August 2021

Publisher's Note: MDPI stays neutra with regard to jurisdictional claims in published maps and institutional affiliations.

Copyright: (c) 2021 by the authors. Licensee MDPI, Basel, Switzerland. This article is an open access article distributed under the terms and conditions of the Creative Commons Attribution (CC BY) license (https:// creativecommons.org/licenses/by/ $4.0 /)$

\begin{abstract}
Designing or expanding a bicycle-sharing system (BSS) involves addressing the infrastructure's location of the bicycle stations. Station location is an essential factor for designing and implementing a new system or for its operation. In a complex spatial optimization context, geographic information systems (GIS) can support this decision problem. There are also numerous ways of subdividing the broad spectrum of location-allocation models used in previous studies. However, a station location comprehensive review and systematization with the specific aim of characterizing the state of the art of BSS is missing. The present research aimed to provide a comprehensive systematization for station location problems, criteria, and techniques, seeking to identify the current state of practice. We searched scientific publication databases to collect relevant publications-the final list comprised 24 papers for the literature review. The systematization addresses the two major problems concerning bicycle station location: initial network design and operation improvement (where changes in operating a BSS are implemented). Based on the literature, we propose a set of four main criteria for choosing appropriate places for bike stations (or parking) in a city: "bike network", "operator", "user", and "city infrastructure". The sub-criteria mentioned in the literature are categorized based on the proposed classification and new sub-criteria are suggested. We also group location modeling techniques into three categories: "mathematical algorithms", "multi-criteria decision making", and "GIS". Combining GIS and multi-criteria decision making (MCDM) has received more attention in recent years to locate bike stations, evaluate their operating performance, and have more accurate and practical results.
\end{abstract}

Keywords: bike-sharing systems; station location; GIS; optimization problem; MCDM; location criteria classification

\section{Introduction}

Bicycle-sharing systems (BSSs) are becoming popular transportation resources in many cities. This transportation mode has many benefits, including a reduction in pollution and traffic. It also contributes to improving users' health [1]. The two most recent generations of BSSs are station-based BSSs (SBSSs) and dock-less BSSs (DBSSs). SBSSs have an infrastructure of stations in a particular area and allow the use of bicycles on a rental and short-term basis. Users can unlock a bike in a station through a membership card or a smartphone app for a period and then return it to the same or another station. As a result, station network accessibility restricts the utilization of SBSSs. For DBSSs, users locate and pick up bikes with their smartphones without such network accessibility restrictions. DBSS users can leave bicycles anywhere inside their operation zone. In addition, DBSS users do not face a station's capacity restrictions (i.e., no empty racks) at the destination. However, both generations face problems. In this study, we refer to physical or virtual stations for SBBSs or DBSSs, respectively. The former issue includes location and capacity (i.e., number of bike racks) restrictions. The latter has mainly a location restriction (although urban 
space for dropping bikes can also be an issue). By responding to SBSS planning and design issues, the corresponding solutions can inform DBSS challenges.

Studies related to BSS infrastructure implementation have focused on a range of diverse problems, from the impact of bicycles on transportation and the associated environmental benefits [2,3], to the promotion of this transportation mode [4] or to demand prediction [5]. Concerning the design of bicycle transportation infrastructure, the components of a system have been addressed in different studies. The characteristics of bicycles [6] and the network dimension [7] are critical aspects to consider when implementing new BSSs. One other type of problem addressed in the literature encompasses the system's operation. Indeed, researchers have focused their studies on operational issues, such as improving the system's efficiency by rebalancing the bicycles among stations [8] and managing the abandoned and irregularly parked bikes in DBSSs via a virtual station. Therefore, to have an efficient network and a decent service, all parts of a BSS must be appropriately designed and operated.

Stations in an SBSS are the most visible component, and their location and capacity have an essential impact on the system operation. Differently, in some DBSSs, based on the decision of the operator to manage the abandoned and irregularly parked bikes, stations are the designated areas as bike parking (virtual stations) that guide users to pick and park bikes there. Therefore, station location is essential in implementing BSS schemes and operations $[9,10]$. Besides, implementing the BSS and encouraging people to use their bikes can be achieved through bicycle infrastructure investments and coupling bicycle stations with parking infrastructures [11]. Each station's best location, whether physical or virtual, must be selected [12] because the proper distribution of stations can play an essential role in increasing bicycle usage [13]. The station locations are mainly designated to balance pick-ups and drop-offs of bicycles in an optimized station network operation. Operators need to have fewer rebalancing expenses in the system and preserve high user satisfaction. Therefore, the location of BSS stations, physical or virtual, is mainly an optimization problem that should provide satisfactory solutions according to specific criteria (e.g., population density, user satisfaction, proximity to public transport) while facing constraints (e.g., budget, available locations).

Two types of problems are the most frequently enumerated in the literature. On the one hand, the design of BSSs, which includes the station's critical location and the system's dimensions (in the case of SBBS), appears to be a primary concern of researchers. It is the first step of any BSS implementation project. On the other hand, many studies have focused on improving BSSs operations, i.e., modifying operating systems to obtain predefined goals related to their performance. Sometimes these two types of problems can be merged in the same study, where optimization algorithms apply. These algorithms are mainly applied to improve the availability, efficiency, and responsiveness of systems. In addition, conflicting criteria arise when we formulate a BSS problem. For instance, initial investment cost, operating cost, and bike distribution cost are the criteria that lead decision makers to build fewer bicycle stations when these criteria receive a higher priority. On the other side, criteria such as user convenience, access to the public transportation network, and proximity of stations all increase the cost of setting up or developing a BSS. For this purpose, multi-criteria decision making may contribute to the comprehensive modeling of the BSS station location problems. At the same time, all BSS location problems have an inherent spatial nature. As such, GIS-based spatial analysis and indicators provide valuable inputs for the production of viable BSS station locations.

The objective of the current study is to provide a systematic literature review focusing on the station location problems and to improve the planning or operation of SBSSs. Some previous reviews focused on techniques such as multi-criteria decision making in the transport sector [14], the use of GIS to measure sustainable urban transport performance [15], or GIS and transportation [16]. However, a comprehensive review and systematization with the specific aim of characterizing state of the art BSSs station location problems are missing. DBSS virtual station locations can develop from this research, as similar challenges are 
faced though with lesser restrictions, for instance, capacity design of station bike racks. Therefore, our literature review addresses two types of problems: planning and design, and operation improvement. In addition, we review and classify modeling techniques into mathematical algorithms, multi-criteria decision making models, and GIS.

The structure of the paper is organized as follows. Section 2 presents the methodology of the research. Section 3 characterizes the research within the scopes of planning and design or operation improvement problems. Identifying modeling techniques for the location of BSS stations will be presented in Section 4. A critical analysis of the selected studies is provided in Section 5 to comprehensively identify criteria and techniques from the literature. Finally, the conclusion summarizes the key findings, providing some practical guidance that may be useful for further research and applications.

\section{Materials and Methods}

Two electronic academic publication databases-Scopus and Web of Science (WoS) were searched in November 2020 to collect the relevant publications. Two types of searches were conducted for peer-reviewed academic journals, specifically research articles and reviews, concerning the location of bicycle stations. The first search based on the title's content, abstract, and keywords focused narrowly on terms related directly to the identified topic, and we found 250 and 200 articles in Scopus and WoS, respectively. As a location problem is an optimization problem, the second search was wider to capture papers investigating "bicycle station location optimization". We found 53 and 44 articles in Scopus and WoS, respectively. Articles that did not focus on bicycle station locations were excluded. We checked 172 papers, identified an overlap of 83 articles, and 89 papers remained. We examined the abstracts of all 89 remaining documents to determine the type of problem or technique addressed. The majority of documents focused on the rebalancing of SBSSs and DBSSs or the effect of rebalancing techniques on its operation. The final list comprised 24 essays for the literature review. Some of these papers (11 in total) focused on the planning and design problems of new BSSs. Thirteen of the articles were related to operation improvement problems for currently operated BSSs. The methodology consists of the steps presented in Figure 1.

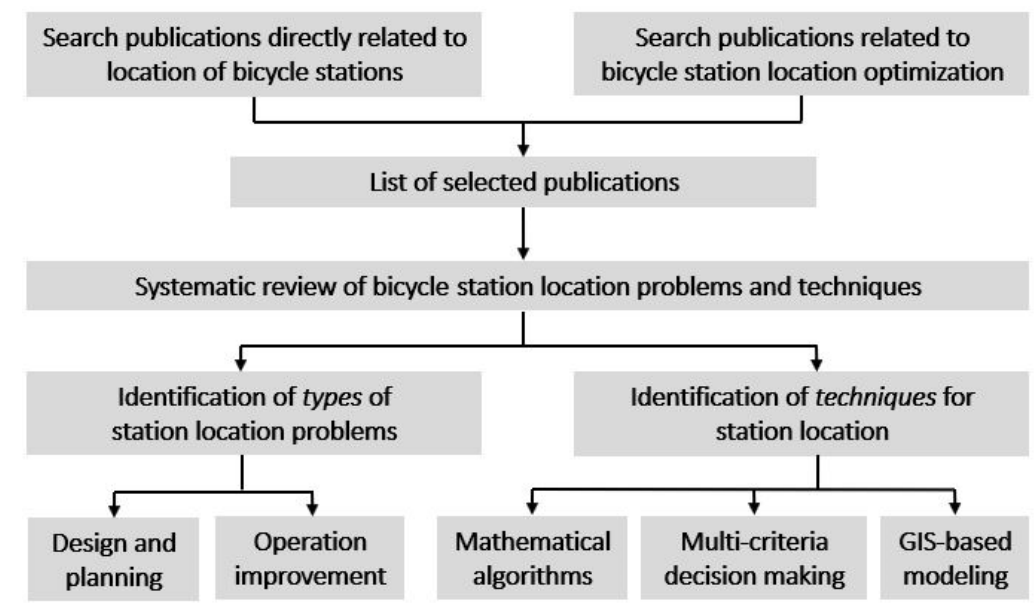

Figure 1. Methodology of the review.

In the next section, we classify each paper as to whether it relates to "Planning and Design Problems" in the case of new BSSs, or "Operation Improvement Problems" when changes occur in an operating BSS. The discussion of the collected case studies and references includes the added value to understanding the BSS planning and design or operational improvement problems. In addition, we present the corresponding context details and station location criteria, such as city size, service density, and operator concerns. Based on the literature, a classification set of a station location's main criteria is proposed: "network", "operator", "user", and "city infrastructure". 


\section{Types of Problems}

A location problem is an optimization problem. The solution proposes a set of appropriate places in a specific area to optimize the value of an objective function while verifying all the given restrictions. Location problems studies began in 1909 to minimize the distance from a warehouse to customers [17]. After that, the classic problems of p-median and p-center were proposed [18]. Since then, facility location studies have intensified, and various models and algorithms have been proposed. These models and algorithms have their advantages and disadvantages in different periods and scenarios. In this study, bike station location problems are divided into "Planning and Design Problems" and "Operation Improvement Problems". Sections 3.1 and 3.2 describe them, respectively.

\subsection{Planning and Design Problems}

All the BSSs are organized by local community groups or non-profit organizations or, on the other hand, by government agencies that manage them mainly through a publicprivate partnership. In this context, studies have identified how to optimally select the location, capacity, and number of stations of BSSs and consider the concerns of users and operators when planning the systems.

Guler and Yomralioglu [19] defined an optimization algorithm coupling station locations and cycling route problems and applied it to a case study in Istanbul, Turkey. They included the following criteria: closeness to shopping centers, bus lines, parks, transportation stations, educational centers, population density, slope, bicycle stations, and cycling lanes. Fazzio et al. [20] used a method to rank station locations optimally while designing better infrastructure and cycle networks in Catania, Italy. The criteria included an index of closeness and accessibility to the public transport system, population, job locations, and parking demand. In Isfahan, Iran, a study concluded that proximity to public transportation networks, bike lanes, type of use, and demand are important factors to find the best station location [13]. With the same goal, a location-allocation model integrated with GIS was proposed for Madrid's city center [21]. The authors considered several criteria in their model: proximity to population, activities, public transport network, and distances between stations.

Similar to the bicycle station location, a study was conducted in Quebec City, Canada, to find the optimal sites for designing bicycle parking infrastructure [11]. The study aimed to promote cycling by presenting a new methodology to identify the optimal locations to install short-term (bicycle racks) and long-term (bicycle lockers or indoor locking facilities) bicycle parking. For this reason, data related to the destinations of existing and potential cyclists and the proximity of the bicycle network to high frequency bus stops were the two priority indexes for finding the locations. A second priority index was then developed that determines where long-term bicycle parking is needed among the sites identified in the previous step. Finally, the authors calculated the number of recommended bicycle parking spaces for these locations.

In parallel to finding the ideal location for bike stations, some researchers have included other factors in their analysis. The number of docks and bikes and in/outcome trips at each station are the three extra vital factors that significantly impact the station location and final network efficiency. In this regard, Chou et al. [22] have examined station location, the number of docks, bikes at each station, and the number of trips (using transit data from the train and bus operators) to design and manage the BSS. The study focused on analyzing the capacity of a BSS to support trips based on the number of bikes and users in the new city of Punggol, Singapore. The authors proposed ideal locations from 16 candidate sites to set up the bicycle stations. Wuerzer et al. [23] presented an algorithm to locate and optimize the number of bikes and stations for Downtown Boise, USA [23]. The main criteria were population density, employment density, higher education, bus stops, bike lanes, parking garages, retail, ATMs, and parks. They proposed a plan with 140 bikes and 14 stations. 
In addition to the above goals, Frade [10] sought to solve the planning and design problem from another angle, i.e., the operator's concerns. The main concern for public/private investors in BSSs is maximizing the benefits through an accurate design and system operation. The author defined a methodology to support decision makers in Coimbra, Portugal. The model locates the stations per zone without setting the station's precise location. The only primary condition is that no site should exceed $500 \mathrm{~m}$ as a suitable estimated walking distance.

BSS demand data of trip origins and destinations (which reflects user needs) is the basis of other studies to determine station location. Lin et al. [24] proposed a new design for a BSS (including potential bicycle station locations) through a hub-location inventory model based on origin-destination matrices. The criteria to select the best place for the station were: $300-500 \mathrm{~m}$ as a minimum distance to important origin or destination bicycle trip generators, minimizing total traveling costs, convenient walking distance, and guaranteeing the availability of bicycles in each station. In addition, the study determined where to build the bicycle lanes, which paths best match origin-destination pairs, and the required inventory level for sharing bicycles at each station to ensure the desired availability [24].

Several studies considered the service density to design a BSS (which reflects the importance of the city infrastructure). One more principle to consider in developing a BSS is user equity. Models for planning and design bike-sharing station locations that include maximization of the coverage and accessibility and equality principles and the connection with public transport aspects have also been proposed [25].

Since most studies were designing a BSS at the city scale, Mete et al. [26] developed the system for the Gaziantep University campus to find the best station location and reduce walking distance. The main criteria of administration were proximity to demand points and availability for possible infrastructure.

\subsection{Operation Improvement Problems}

With the increase of citizen awareness and their longing for using BSSs and for city managers worldwide to follow the UN Vision 2030, the development of BSSs and their accessibility for all citizens in a city has intensified. To this end, studies identified how to select the location, capacity, and number of new stations, and consider the concerns of users and operators in the improvement modeling.

Many studies have suggested adding new stations to the existing networks by considering different criteria. A study in Montréal, Canada, developed a methodology to plan effective additions to an existing bicycle network [27], using several indicators to demonstrate how to prioritize different possible new locations for bicycle facilities. Another study was carried out to find the best location for stations, and to rank and prioritize them in a BSS [28], by considering land types, amount of available space, accessibility to main bike routes, and walkability to destinations. Kabak et al. [29] evaluated the current status of a BSS in Karsiyaka, Izmir (Turkey), and proposed new station locations for the system using 12 criteria in the evaluation. Banerjee et al. [30] studied the expansion of the BSS in Baltimore, USA, focusing on the intensity of road segment usage and identifying optimal locations for new stations. The location criteria included closeness to transit, attractions, restaurants/pubs, and existing bike stations.

The optimization of virtual station locations was addressed in a study of the DBSS of Beijing, China [31]. Although some studies aimed to find virtual stations or zones for new stations, some studies sought to pinpoint exact locations of new stations. Various techniques support the characterization of possible sites, such as questionnaires [27,32], where several locational criteria can be identified. An exciting criterion for the new station location is considering user residence locations [9], where station location criteria included the distance from user residence location and proximity to current stations (considering that each station has an area of influence). Another important criterion that significantly impacts the station's location is the uncertainty of traveler demands. For that, hybrid algorithms for location-allocation of bike stations can be developed [33], optimizing the station locations 
while considering the need to minimize time and travel costs. However, cities often lack data on BSSs travel demand and the interaction with the remaining transport system, namely public transportation, which is a crucial pitfall when planning and designing new or expanding existing BSSs. Such missing data is even more problematic when BSSs are essential complements to public transportation as facilitators of the first-and-last miles.

Another important factor in network development is the initial budget allocated to the project and the extent to which bicycle stations can be spatially distributed to enhance station accessibility while also attaining spatial and social equity. A study [34] concluded that many stations were needed to expand a BSS to better cover the region being studied. However, because of the limitation of initial investment, the number of stations required for a given level of service was found, enabling the problem of selecting station locations based on investment level. By considering user and operator related criteria, criteria related to the city infrastructure also influence network development. In this regard, to help the companies to maintain and manage their bicycles and service sites, a study [35] focused on selecting the optimal service sites for Mobikes in Fuzhou, China. They planned the shortest circuit between service sites using city infrastructure criteria such as population density and neighborhood size.

In addition to the bicycle station location, further research considered other factors in network development. A study [36] was conducted to identify the shortage of bikes and racks in a BSS in Taipei, Taiwan, and to determine site selection of further rental stations. Five main criteria of demographic variables, accessibility, the attractiveness of the shopping district, the potential for development, and competitiveness (designed by planners compared with suggested by people) were considered. Griffin and Jiao [37] examined the difference between station location proposals with a higher detail level from planners and citizens. The study evaluated the impact of participant input via a public participation geographic information system (PPGIS) to suggest the location of new BSS stations in New York City and Chicago. The study found that the suggestions offered by PPGIS have a significant impact on the knowledge and insights of planners in designing the BSS and station location.

Sometimes, the goal of city managers in developing a BSS is not precisely because of the high demand of cyclists. Sometimes networks are designed to encourage other citizens who mostly use different modes of transportation. For example, Yogyakarta is the fourth most congested city in Indonesia, highlighting the importance of changing the transportation mode from private vehicles to public transportation. With this purpose in mind, a study [38] developed a currently operating BSS consisting of only 12 stations, trying to find the optimal location for new stations by considering 13 criteria in the model. Sometimes, the issue is related to the density and inequitable distribution of services, where BSSs do not reach low-income areas in a city (see [34]).

\section{Location Techniques}

There are numerous ways of subdividing the broad spectrum of location and allocation models used in previous studies. The taxonomy of location models includes analytic, continuous, network, and discrete models, all well-known and familiar modeling techniques [39]. While analytical models assume that demand is distributed uniformly across a service area, continuous models typically assume it occurs at discrete network points. Network models assume that demand and facilities are addressed as a network composed of nodes and links and focus mainly on finding polynomial-time algorithms. Discrete models address BSS demand at the nodes and stations are restricted to a finite set of candidate locations. The discrete location models are also divided into three parts: covering-based models (with three subdividing: set covering, max covering, p-center), median-based models (with two subdividing: p-median, fixed charge), and other models [40].

In this review, the techniques related to bike-sharing station locations that were used in the literature are categorized as "mathematical algorithms", "multi-criteria decision making", and "GIS-based modeling", and are addressed in Sections 4.1-4.3, respectively. 


\subsection{Mathematical Algorithms}

Location models include three types of performance indicators to balance the service quality and efficiency of a BSS: availability (set covering location model), efficiency (maximal covering location model), and responsiveness (p-median location model). Availability implies whether a service facility is located within a customer's preferred distance. Efficiency refers to the maximum rate of customer satisfaction a service can deliver with limited facilities. Responsiveness is the ability to provide service to customers promptly, which is regarded as minimizing the total/average travel distance between customers and service facilities in a location-based analysis [40]. In similar research [26], a set of location problem formulations ( $\mathrm{p}$-median, $\mathrm{p}$-center, maximal covering, set covering, and undesirable facility location models) were applied to determine station locations for a given demand. The study concluded that the p-median solution was more effective in determining station locations considering accessibility because it produced uniform coverage.

An optimization model was also proposed [25] to maximize the aspects of coverage, accessibility, and equality simultaneously under a limited available budget. The study's results show that the proposed model is efficient and that an increase in accessibility and coverage guarantees a decrease in inequality and discrimination among the various users. The station's size and the origin-destination demand were not considered in their model. To find the ideal station locations, the number of docks and bikes at each station, stochastic network flow models to estimate the flow of bikes, and the distribution of bicycles in the stations can be used [22]. Transit data from the train and bus operators were used to perform the numerical analysis. The study concluded that allocating and distributing enough bicycles to well-located stations is essential to develop an effective BSS.

Optimization models usually consider an available budget as a constraint, maximizing the system's benefits by covering the demand and the return on investment, solved with optimization software [10]. The model can determine the optimal location of the bicycle stations at each zone the study area is divided into and the fleet size, the capacity of the station, and the number of bicycles in each station, considering an initial investment lower than the given budget constraint.

Some studies have based their analysis on the history of network demand or its forecast. A real-time optimization problem used a mixed-integer linear programming (MILP) model to maximize the user demand with a clustering algorithm [31]. The experimental results demonstrated that the MILP model and the proposed method are superior to the examined K-means method. Jin et al. [35] used data collected from Mobikes in the five districts to select service sites and plan the shortest circuit connecting sites. Density-based clustering algorithms and ant colony algorithms were used in the study. The former analyzed the experimental data and determined the number and location of service sites. In contrast, the latter was applied for planning the shortest circuits. The scatter diagram of the distribution of the Mobikes was carried out by using GIS. Demand in studies can be assumed to be constant or applied under uncertain status in the model. A locationallocation model, including capacity decisions, and the sample average approximation (SAA) method were used in [33] to find optimal bike stations in uncertain demand. Because of the problem's NP-hardness, a hybrid greedy/evolutionary algorithm was developed based on genetic and particle swarm optimization. Their results confirmed the validity of the proposed model and the efficiency of the hybrid algorithm. In a different work, a hub location inventory model was formulated to address the BSS design problem through an integrated view [24]. The hub location problem involves determining the hub facilities and determining the links to connect origins, destinations, and hubs. The presented formulation was not computationally tractable, and the authors proposed a greedy heuristic method to efficiently find near-optimal solutions.

Some studies have undertaken their analysis by surveying people or experts. Shu et al. [32] conducted a questionnaire survey in 220 bicycle stations, with seven land-use categories according to type and sixteen according to intensity. A binary logistic model was also developed to verify that users with different travel purposes have different walking 
distances. The study concluded that the users choose stations within close walking distance and that a shorter length improves user' satisfaction.

\subsection{Multi-Criteria Decision Making}

Multi-criteria decision making (MCDM) helps decision makers to solve complex decision problems in a scientific and analytical framework. Some models and processes that fit into this category are:

- Analytical hierarchy process (AHP), e.g., AHP/fuzzy or AHP/ANP, which make a pairwise comparison of some criteria and then weight elements to identify the best alternative.

- ELECTRE, which determines preferred alternatives based on two indices called the concordance index and the discordance index.

- TOPSIS, which examines the best alternative or criteria according to the shortest and farthest distance from the positive and the negative ideal solution, respectively.

- PROMTHEE, that finds the optimal alternative that best matches the objectives and understanding of the problem.

- MOORA, that optimizes two or more overlying objectives under constraints.

- HYBRID modeling, which combines two different methodologies, mostly MCDM, with other methods, such as a combination with GIS (i.e., GIS-MCDM). Because of their advantages and disadvantages, they are mostly applied separately or integrated with other methods.

The optimal station location can be studied by incorporating mathematical programming and AHP, with appropriate goals and locational criteria [13], weighted through MCDM methods. The final scores of every point can be calculated by maximizing the utility of stations and minimizing station establishment costs in every region. In addition, analyses of questionnaires distributed among experts can support the evaluation of accessibility to the main bike route, walkability to destinations, amount of available space, and the types of land, with the goal of ranking suitable locations [28]. BSSs can be planned by combining MCDM methods and GIS. This combination can be further supported by AHP to obtain the weights of criteria for multi-objective optimizations and evaluate current and potential alternatives. In a Turkish city, Kabak et al. [29] found that the most crucial factor from the transport network dimension was the proximity to the cycling lanes and the lowest priority was the proximity to primary or secondary schools.

\subsection{GIS-Based Modeling}

The usage of GIS is advantageous for bicycle station locations, as GIS allows for the efficient and effective gathering, managing, and analyzing of geographical data. The geographical elements, land use, cost, and environmental impact are usually the crucial criteria in the station location domain. Some studies have used GIS-based multi-criteria analysis tools to evaluate and analyze some goals, such as finding the optimal bicycle infrastructures, the distribution of potential demand, and the optimal bike station location.

The literature on methods for identifying new locations for bicycle facilities is scarce. A GIS-based grid cell model for bicycle facility prioritization and location can provide the flexibility to include various relevant, readily available data sources in an easily interpretable graphical format suitable for decision makers and the public [27]. This method supported a study [11] that presented a new methodology to identify the optimal locations using a GIS-based approach that considers multiple criteria. According to some identified indicators, the study area was divided into $300 \mathrm{~m}$ by $300 \mathrm{~m}$ grid cells, and a prioritization index for new bicycle parking was generated. The indicators were then combined, and a weighting scheme was applied. Only grid cells within $100 \mathrm{~m}$ of the existing bicycle network were selected. The recommended number of parking spaces for each grid cell was then calculated according to the current parking supply and the existing and potential demand for bicycle parking. 
GIS-based models also identify the lack of bike sites and bike rack hot spots utilizing spatial-temporal analysis. Wang et al. [36] applied retail location theory to determine the site selection of rental stations in Taiwan. The study concluded that spatial-temporal analysis could be used to effectively determine the most suitable bike station locations. The GIS-based method can also calculate the spatial distribution of the potential demand for trips. García-Palomares et al. [21] located stations using location-allocation models and determined station capacity (number of docks), defining the characteristics of the demand for stations (the number of docks and bicycles at each station), and evaluating different scenarios with variations in the number of stations. The authors tested two of the most common solutions in location-allocation models: minimizing impedance and maximizing coverage. The first approach allows the station location to be optimized to minimize the distance between supply and demand. The second approach attempts to optimize the total population covered within a particular fixed radius. Another study focused on location coverage models to site bike stations to provide an equitable spatial distribution using spatial analytics, including GIS and spatial optimization [34]. A set of stations provided the best access to a designated bike path network for the most significant number of potential users for a given investment level.

Some researchers have used a combination of several techniques of MCDM in their studies. A study that integrates MCDM and fuzzy GIS to address the problem of where to build BSS stations and bikeways has adopted MCDM to compare a series of identified location-related criteria and decide which criterion is more efficacious [19]. MCDM methods (AHP, FAHP, and BWM) were used in the study to rank alternative locations. GIS was a helpful tool, as spatial analyses were used to provide spatial indicators for criteria evaluation. The proposed technique simultaneously finds suitable locations for BSS stations and bike lanes, promoting effective land use planning. Fazio et al. [20] combined GIS-based and MSDM methods to define the priority ranking of station locations through a spatial analysis combined with a multi-criteria approach. In the first step, the study area was divided into zones $(\mathrm{a} 100 \times 100 \mathrm{~m}$ mesh grid) to discretize the corresponding spatial attributes and achieve a high degree of detail on the positioning of the facilities being studied. Each location was confirmed within a radius of a predetermined threshold distance from an existing cycle route. Otherwise, it was deleted. Finally, a choice was made regarding the type of parking facilities, based on short- or long-term parking needs. The study concluded that a spatial approach is required in the BSS, which incorporates infrastructure, network, and station location. The study also concluded that the applied methodology efficiently connects the origin to the destination and guarantees safety. Identifying the best location for siting bicycle-sharing stations can use a mix of AHP and spatial multi-criteria analysis. In a case study in Yogyakarta [38], three main criteria of the transport network, land use, and demand with 13 sub-criteria were used in the analysis. According to the created suitability map of bike sharing, the study proposed the location of new stations.

Some researchers have used a combination of GIS and mathematical models in their studies. For example, in a study conducted on a university campus [26], 20 demand points and 20 potential bike station sites were determined as point features, and campus roads were vectored as line features via GIS. The study used GIS software combined with mathematical models. GIS optimization analysis can be used to determine the optimal number of bikes and bike stations [23]. New bike station locations can be extracted using a location-allocation spatial analysis tool and a gravity model [30].

Few studies investigate the role and impact of online platforms on planning outcomes to reach better station location techniques. Griffin and Jiao [37] used participatory GIS (PPGIS) to conduct two analyses-proximity and geospatial analysis- to evaluate how close planners built new bike share stations to those suggested on PPGIS platforms. According to the first analysis, only a small percentage of the stations were located within $30 \mathrm{~m}$ of proposed stations. However, a second analysis showed a substantial clustering of suggested and built stations in both cities that was not likely due to a random distribution. The results of [9] were obtained with a location-allocation model coupled with GIS, which 
assigns each user an impedance value from each station. Addressing location-allocation using GIS enables inspecting how a BSS could be well planned and consolidated.

Based on Sections 3 and 4, Tables 1 and 2 summarize the findings of the literature review.

A comprehensive and systematic classification of some critical items such as "Goals", "Context", "Location criteria", "Added value", and "Techniques" were extracted from the target papers in Tables 1 and 2, respectively for, "Planning and Design Problems" and "Operation Improvement Problems".

Table 1. Overview of literature on planning and design of BSSs.

\begin{tabular}{|c|c|c|c|c|c|}
\hline Ref. & Goals & Context & Location Criteria & Added Value & Techniques \\
\hline$[10]$ & $\begin{array}{l}\text { optimize the } \\
\text { location of stations, } \\
\text { fleet size, capacity } \\
\text { of stations, number } \\
\text { of bicycles in each } \\
\text { station }\end{array}$ & $\begin{array}{l}\text { population: more than } \\
140,000 \text { in } 2011,18 \% \text { of } \\
\text { daily trips are taken in } \\
\text { public transport, } \\
57 \% \text { of trips are less } \\
\text { than } 4 \mathrm{~km}\end{array}$ & $\begin{array}{l}\text { optimization } \\
\text { model based on } \\
\text { the demands of } \\
\text { each zone; no zone } \\
\text { should exceed a } \\
\text { maximum distance } \\
\text { between any } \\
\text { two points }\end{array}$ & $\begin{array}{l}\text { the model considered } \\
\text { the maximization of } \\
\text { the benefits for } \\
\text { investors and it } \\
\text { involves maximizing } \\
\text { the number of users }\end{array}$ & $\begin{array}{l}\text { mathematical } \\
\text { algorithms }\end{array}$ \\
\hline [11] & $\begin{array}{l}\text { to develop a } \\
\text { practice-ready } \\
\text { GIS-based method } \\
\text { to identify optimal } \\
\text { locations }\end{array}$ & $\begin{array}{l}\text { pop. } 531,902(2016), \\
\text { area: } 454 \mathrm{~km}^{2}, \text { ca. } \\
424 \mathrm{~km} \text { of bikeways }\end{array}$ & $\begin{array}{l}\text { proximity of } \\
\text { cycling network to } \\
\text { bus stops, OD } \\
\text { existing cyclists, } \\
\text { OD potential } \\
\text { cyclists, proximity } \\
\text { to existing } \\
\text { bike parking }\end{array}$ & $\begin{array}{l}\text { developed a } \\
\text { methodology to } \\
\text { precisely identify the } \\
\text { optimal locations of } \\
\text { long-term and } \\
\text { short-term bicycle } \\
\text { parking and stations }\end{array}$ & $\begin{array}{l}\text { combines GIS and } \\
\text { MCDM }\end{array}$ \\
\hline [13] & $\begin{array}{l}\text { find the criteria of } \\
\text { stations location, } \\
\text { finding the best } \\
\text { locations of } \\
\text { stations }\end{array}$ & $\begin{array}{l}14 \text { areas in the city } \\
\text { were proposed to have } \\
\text { new stations }\end{array}$ & $\begin{array}{l}\text { bicycle path, } \\
\text { public transport } \\
\text { and road networks, } \\
\text { use type, demand }\end{array}$ & $\begin{array}{l}\text { comprehensive model } \\
\text { by combining } \\
\text { mathematical } \\
\text { programming and } \\
\text { multi-criterion } \\
\text { decision-making } \\
\text { techniques }\end{array}$ & $\begin{array}{l}\text { combines MCDM } \\
\text { and mathematical } \\
\text { algorithms }\end{array}$ \\
\hline [19] & $\begin{array}{l}\text { determine } \\
\text { locations of } \\
\text { stations and } \\
\text { bicycle lanes } \\
\text { together }\end{array}$ & pop. 15 million (2018) & $\begin{array}{l}\text { closeness to points } \\
\text { of interest }\end{array}$ & $\begin{array}{l}\text { workflow that } \\
\text { combines GIS and } \\
\text { MCDM methods }\end{array}$ & $\begin{array}{l}\text { combines GIS and } \\
\text { MCDM }\end{array}$ \\
\hline [20] & $\begin{array}{l}\text { prioritization of } \\
\text { locations of the } \\
\text { cycle stations } \\
\text { within an urban } \\
\text { area, in } \\
\text { combination with } \\
\text { the design of a } \\
\text { cycle network }\end{array}$ & $\begin{array}{l}\text { pop. } 300,000 \\
\text { inhabitants; poor } \\
\text { bicycle infrastructure }\end{array}$ & $\begin{array}{l}\text { closeness and } \\
\text { accessibility to the } \\
\text { public transport } \\
\text { system, } \\
\text { population, job } \\
\text { locations, } \\
\text { parking demand }\end{array}$ & $\begin{array}{l}\text { propose a GIS-based } \\
\text { approach to solve the } \\
\text { location problem of } \\
\text { bike parking }\end{array}$ & $\begin{array}{l}\text { combines GIS and } \\
\text { MCDM }\end{array}$ \\
\hline [21] & $\begin{array}{l}\text { optimize station } \\
\text { location, identify } \\
\text { the station's main } \\
\text { characteristics, and } \\
\text { assess the utility of } \\
\text { each station }\end{array}$ & $\begin{array}{l}\text { pop. } 1.1 \text { million; } 0.1 \% \\
\text { of trips are made by } \\
\text { bicycle }\end{array}$ & $\begin{array}{l}\text { proximity to } \\
\text { population, } \\
\text { activities, public } \\
\text { transport network, } \\
\text { distances } \\
\text { between stations }\end{array}$ & $\begin{array}{l}\text { use location-allocation } \\
\text { models to optimize } \\
\text { station location }\end{array}$ & $\begin{array}{l}\text { combines GIS and } \\
\text { MCDM }\end{array}$ \\
\hline
\end{tabular}


Table 1. Cont.

\begin{tabular}{|c|c|c|c|c|c|}
\hline Ref. & Goals & Context & Location Criteria & Added Value & Techniques \\
\hline [22] & $\begin{array}{l}\text { identify the station } \\
\text { location, the } \\
\text { number of docks, } \\
\text { bikes at each } \\
\text { station, and the } \\
\text { number of trips }\end{array}$ & $\begin{array}{l}\text { new town with est. } \\
\text { pop. } 59,200\end{array}$ & $\begin{array}{l}\text { the most traversed } \\
\text { route, MRT Station, } \\
\text { LRT Station peaks }\end{array}$ & $\begin{array}{l}\text { conduct a numerical } \\
\text { analysis using transit } \\
\text { data }\end{array}$ & $\begin{array}{l}\text { mathematical } \\
\text { algorithms }\end{array}$ \\
\hline [23] & $\begin{array}{l}\text { locates and } \\
\text { optimizes the } \\
\text { number of bikes } \\
\text { and stations }\end{array}$ & $\begin{array}{l}\text { ca. } 205,000 \text { residents, } \\
\text { over } 32 \mathrm{~km} \text { network, } \\
\text { area of approx. } \\
3.6 \mathrm{~km} \text { in diameter }\end{array}$ & $\begin{array}{l}\text { population density, } \\
\text { employment } \\
\text { density, proximity } \\
\text { to points of interest }\end{array}$ & $\begin{array}{l}\text { use GIS optimization } \\
\text { analysis to determine } \\
\text { the optimal number of } \\
\text { bikes and bike stations }\end{array}$ & $\begin{array}{l}\text { combines GIS and } \\
\text { mathematical } \\
\text { algorithms }\end{array}$ \\
\hline [24] & $\begin{array}{l}\text { find the number } \\
\text { and location of } \\
\text { stations, creation } \\
\text { of bicycle lanes, } \\
\text { selection of paths } \\
\text { of users between } \\
\text { origins and } \\
\text { destinations, } \\
\text { inventory levels at } \\
\text { stations, } \\
\text { considering total } \\
\text { cost and service } \\
\text { levels }\end{array}$ & $\begin{array}{l}\text { case study with four } \\
\text { bus stations, two mass } \\
\text { rapid transit stations, } \\
\text { six office buildings, } \\
\text { and eleven candidate } \\
\text { sites for stations }\end{array}$ & $\begin{array}{l}\text { minimize the sum } \\
\text { of traveling costs, } \\
\text { convenient } \\
\text { walking distance, } \\
\text { proximity to } \\
\text { important origins } \\
\text { and destinations } \\
\text { of traffic }\end{array}$ & $\begin{array}{l}\text { create a model to } \\
\text { develop methods for } \\
\text { obtaining solutions for } \\
\text { the design variables in } \\
\text { practical situations }\end{array}$ & $\begin{array}{l}\text { mathematical } \\
\text { algorithms }\end{array}$ \\
\hline [25] & $\begin{array}{l}\text { new model for } \\
\text { station location }\end{array}$ & $\begin{array}{l}\text { a network with a grid } \\
\text { of } 3.0 \times 3.6 \mathrm{~km} \\
\text { composed of streets, } \\
\text { three bus lines with } \\
\text { bus stops and } \\
\text { potential bike stations, }\end{array}$ & $\begin{array}{l}\text { maximum cycling } \\
\text { distance, } \\
\text { maximum walking } \\
\text { distance, proximity } \\
\text { to bus stops, } \\
\text { station } \\
\text { construction } \\
\text { budget }\end{array}$ & $\begin{array}{l}\text { link the location } \\
\text { design of a BSS to } \\
\text { urban public transport } \\
\text { lines considering } \\
\text { social equality } \\
\text { principles }\end{array}$ & $\begin{array}{l}\text { mathematical } \\
\text { algorithms }\end{array}$ \\
\hline [26] & $\begin{array}{l}\text { find possible } \\
\text { locations of the } \\
\text { stations for users } \\
\text { (students) }\end{array}$ & $\begin{array}{l}\text { pop. 1,975,302 (2016), } \\
\text { university has } 40,000 \\
\text { population, area } \\
311 \text { ha }\end{array}$ & $\begin{array}{l}\text { proximity to } \\
\text { demand points, } \\
\text { available for } \\
\text { possible } \\
\text { infrastructure }\end{array}$ & $\begin{array}{l}\text { five different } \\
\text { location-allocation } \\
\text { models were } \\
\text { implemented to the } \\
\text { bike location problem }\end{array}$ & $\begin{array}{l}\text { combines GIS and } \\
\text { mathematical } \\
\text { algorithms }\end{array}$ \\
\hline
\end{tabular}

Table 2. Overview of literature on operation improvement of BSSs.

\begin{tabular}{|c|c|c|c|c|c|}
\hline Ref. & Goals & Context & Location Criteria & Added Value & Techniques \\
\hline [9] & $\begin{array}{l}\text { optimize the location } \\
\text { of bike stations }\end{array}$ & $\begin{array}{l}415,124 \text { inhab., } \\
508 \mathrm{~km}^{2}, \text { BSS } \\
\text { operating for two } \\
\text { years, } 135 \text { bikes, } \\
8 \text { stations }\end{array}$ & $\begin{array}{l}\text { distance from user's } \\
\text { residence location, proximity } \\
\text { to current stations }\end{array}$ & $\begin{array}{l}\text { evaluate the location of } \\
\text { bike stations based on the } \\
\text { location of the system's } \\
\text { users }\end{array}$ & GIS \\
\hline [27] & $\begin{array}{l}\text { show how GIS can be } \\
\text { used to help } \\
\text { effectively plan } \\
\text { additions to an } \\
\text { existing bicycle } \\
\text { network }\end{array}$ & $\begin{array}{l}\text { pop. } 3.7 \text { million, total } \\
\text { of } 425 \mathrm{~km} \text { of cycling } \\
\text { facilities }\end{array}$ & $\begin{array}{l}\text { actual and potential bicycle } \\
\text { trips, segments of bicycle } \\
\text { paths suggested by the } \\
\text { survey, bicycle-vehicle } \\
\text { collision data, presence of } \\
\text { dangling nodes, or cycling } \\
\text { facilities ending abruptly }\end{array}$ & $\begin{array}{l}\text { presenting a GIS-based, } \\
\text { grid cell model for bicycle } \\
\text { facility prioritization and } \\
\text { location }\end{array}$ & GIS \\
\hline [28] & $\begin{array}{l}\text { prioritization suitable } \\
\text { locations of bike } \\
\text { stations in each zone } \\
\text { by using AHP }\end{array}$ & $\begin{array}{l}\text { CBD with } \\
200-300 \mathrm{~km}^{2}\end{array}$ & $\begin{array}{l}\text { type of land, amount of } \\
\text { available space, accessibility } \\
\text { to main bike routes, } \\
\text { walkability to destinations }\end{array}$ & $\begin{array}{l}\text { application of AHP to } \\
\text { rank suitable locations of } \\
\text { bike stations }\end{array}$ & $\operatorname{MCDM}(\mathrm{AHP})$ \\
\hline
\end{tabular}


Table 2. Cont.

\begin{tabular}{|c|c|c|c|c|c|}
\hline Ref. & Goals & Context & Location Criteria & Added Value & Techniques \\
\hline [29] & $\begin{array}{l}\text { locate future station } \\
\text { sites by comparing } \\
\text { them to existing } \\
\text { stations }\end{array}$ & $\begin{array}{l}\text { pop. } 342,062, \text { area } \\
25,437 \mathrm{~km}^{2}, 130 \text { bikes }\end{array}$ & $\begin{array}{l}\text { proximity to points of interest, } \\
\text { population density, transit } \\
\text { hubs }\end{array}$ & $\begin{array}{l}\text { different MCDM } \\
\text { methods were combined } \\
\text { with GIS }\end{array}$ & $\begin{array}{l}\text { combines GIS } \\
\text { and MCDM }\end{array}$ \\
\hline$[30]$ & $\begin{array}{l}\text { identify the top three } \\
\text { locations for bike } \\
\text { station placements }\end{array}$ & 21 bike stations & $\begin{array}{l}\text { proximity to points of interest, } \\
\text { existing stations }\end{array}$ & $\begin{array}{l}\text { gravity model, replacing } \\
\text { facility location size with } \\
\text { a suitability score }\end{array}$ & $\begin{array}{l}\text { GIS and Huff's } \\
\text { gravity model }\end{array}$ \\
\hline [31] & $\begin{array}{l}\text { optimize the location } \\
\text { assignment of virtual } \\
\text { stations }\end{array}$ & & maximize user demand & $\begin{array}{l}\text { proposed mixed models } \\
\text { to find the location and } \\
\text { maximize user demand }\end{array}$ & $\begin{array}{l}\text { mathematical } \\
\text { algorithms }\end{array}$ \\
\hline$[32]$ & $\begin{array}{l}\text { optimize distance } \\
\text { between the building } \\
\text { entrance/exit and the } \\
\text { station to determine } \\
\text { exact station } \\
\text { locations }\end{array}$ & $\begin{array}{l}\text { public bicycle } \\
\text { stations located in } \\
\text { eight types of land } \\
\text { use; questionnaire } \\
\text { survey conducted in } \\
220 \text { stations }\end{array}$ & $\begin{array}{l}\text { transport hub, residential and } \\
\text { commercial districts, office } \\
\text { area, schools, scenic area \& } \\
\text { park, other (large/small } \\
\text { amenity) }\end{array}$ & $\begin{array}{l}\text { determine the exact } \\
\text { station locations to } \\
\text { minimize the walking } \\
\text { distance }\end{array}$ & $\begin{array}{l}\text { mathematical } \\
\text { algorithms }\end{array}$ \\
\hline [33] & $\begin{array}{l}\text { optimize the stations, } \\
\text { considering } \\
\text { minimizing time and } \\
\text { travel cost }\end{array}$ & $\begin{array}{l}\text { CBD, OD nodes were } \\
\text { selected close to the } \\
\text { public and important } \\
\text { centers }\end{array}$ & $\begin{array}{l}\text { construction cost, traveling } \\
\text { cost, demand, public and } \\
\text { essential centers }\end{array}$ & $\begin{array}{l}\text { considering stochastic } \\
\text { demands, and adopt a } \\
\text { hybrid algorithm }\end{array}$ & $\begin{array}{l}\text { mathematical } \\
\text { algorithms }\end{array}$ \\
\hline [34] & $\begin{array}{l}\text { assessment of the } \\
\text { number and location } \\
\text { of stations }\end{array}$ & $\begin{array}{l}\text { to assess the number } \\
\text { of stations and their } \\
\text { location }\end{array}$ & $\begin{array}{l}\text { the initial investment, } \\
\text { walking distance, location } \\
\text { coverage, demand coverage }\end{array}$ & $\begin{array}{l}\text { utilizing spatial analytics, } \\
\text { including GIS and spatial } \\
\text { optimization }\end{array}$ & GIS \\
\hline$[35]$ & $\begin{array}{l}\text { selecting optimal } \\
\text { service sites and } \\
\text { planning the shortest } \\
\text { circuit planning } \\
\text { between service sites } \\
\text { in each region }\end{array}$ & $\begin{array}{l}\text { one week of data } \\
\text { collection, } \\
94,310 \text { bicycles }\end{array}$ & $\begin{array}{l}\text { population density, demand, } \\
\text { neighborhood size }\end{array}$ & $\begin{array}{l}\text { using a density-based } \\
\text { clustering algorithm and } \\
\text { an improved ant colony } \\
\text { algorithm }\end{array}$ & $\begin{array}{l}\text { mathematical } \\
\text { algorithms and } \\
\text { GIS }\end{array}$ \\
\hline [36] & $\begin{array}{l}\text { identify lacking bike } \\
\text { and/or lacking bike } \\
\text { rack hot spots and } \\
\text { determine site } \\
\text { selection of further } \\
\text { stations }\end{array}$ & $\begin{array}{l}196 \text { stations, } \\
8934 \text { racks, } \\
6406 \text { bikes }\end{array}$ & $\begin{array}{l}\text { demographic variables, } \\
\text { accessibility, attractiveness of } \\
\text { shopping district, potential } \\
\text { for development, } \\
\text { competitiveness }\end{array}$ & $\begin{array}{l}\text { using spatial-temporal } \\
\text { analysis and retail } \\
\text { location theory to } \\
\text { determine stations site } \\
\text { selection }\end{array}$ & GIS \\
\hline$[37]$ & $\begin{array}{l}\text { investigate the role } \\
\text { and impact of an } \\
\text { online platform on } \\
\text { planning outcomes in } \\
\text { station location }\end{array}$ & - & - & $\begin{array}{l}\text { participatory GIS to } \\
\text { evaluate the suggested } \\
\text { and built station location }\end{array}$ & participatory GIS \\
\hline$[38]$ & $\begin{array}{l}\text { finding the optimal } \\
\text { location of the station }\end{array}$ & $\begin{array}{l}\text { pop. } 422,732(2017) \\
\text { pop. density of } \\
13,007 \text { inhab. } / \mathrm{km}^{2}\end{array}$ & proximity to points of interest & $\begin{array}{l}\text { mixed spatial analysis } \\
\text { using AHP and GIS }\end{array}$ & $\begin{array}{l}\text { combines GIS } \\
\text { and MCDM }\end{array}$ \\
\hline
\end{tabular}

\section{Results and Discussion}

Section 5.1 presents an analysis of Section 3. Finally, for identifying the advantages and disadvantages of the mentioned techniques in Section 4, an analysis is provided in Section 5.2.

\subsection{Analysis of Types of Problems}

In a location problem context, some criteria should be considered for choosing appropriate places for bike stations (or parking) in a city. To the best of our knowledge, there is a research gap in identifying, systematizing, and collecting data of applicable criteria for locating and classifying bicycle stations. Therefore, based on the literature, a classification of main criteria is proposed in this study: "bike network", "operator", "user", and "city infrastructure". Each category includes a series of sub-criteria, which, alone or in interaction with each other, influence the location of stations. The "bike network" includes sub-criteria that directly depend on its components, such as station, station capacity, number of bicycles in the system, and bike lanes. Initial budget, network maintenance cost, and system balancing cost are related totally to the "operator." Maximum walking distance, history of user transactions data, level of satisfaction, and trip safety are among the "user" criteria. Several factors also relate to the implementation environment of a BSS, 
including city size, other public transportation, landscape, points of interest (POI), and the population that refers to the city infrastructure.

- Location criteria

Table 3 presents all the criteria considered in previous studies for "initial network design" and "operation improvement".

Table 3. The station location criteria used in the literature.

\begin{tabular}{cr}
\hline Main Criteria & Sub-Criteria \\
\hline Bike network (C1) & $\begin{array}{c}\text { demand points/zones (consist of proximity to OD existing cyclists, OD potential } \\
\text { cyclists, OD bike parking, job locations, OD of traffic, possible infrastructure) (C1-1), } \\
\text { most traversed route (C1-2), maximum distances between stations (C1-3), cycling } \\
\text { infrastructure (bike parking, bicycle path, number of bikes and stations in system, } \\
\text { number of docks in stations) (C1-4) }\end{array}$ \\
\hline Operator (C2) & $\begin{array}{r}\text { station construction budget (C2-1), traveling costs (C2-2) } \\
\text { User (C3) }\end{array}$ \\
\hline City infrastructure (C4) & $\begin{array}{c}\text { (C3-2), user transection in other public modes (C3-3), user safety (C3-4) } \\
\text { points of interest (schools, scenic area, parks, etc.) (C4-1), population density (C4-2), } \\
\text { employment density (C4-3), public transport system (consist of proximity to bus stops, } \\
\text { MRT Station, LRT station) (C4-4), city and neighborhood size (C4-5) }\end{array}$ \\
\hline
\end{tabular}

In addition to the criteria listed in Table 3, researchers have considered additional criteria in the development stage listed in Table 4.

Table 4. The extra station location criteria used in literature, in the stage of operation improvement.

\begin{tabular}{cr}
\hline Main Criteria & Sub-Criteria \\
\hline Bike network (C1) & competitiveness (C1-5), network connectivity (C1-6) \\
\hline Operator (C2) & initial investment budget (C2-3) \\
\hline User (C3) & distance from user residence location (C3-5), bicycle-vehicle collision data (C3-6), \\
historical user transection (C3-7)
\end{tabular}

By considering the criteria of both tables, having a flawless operation and balanced pick-ups and drop-offs of bicycles among stations will be expected for both stages of design and expansion. Therefore, operators need to have fewer rebalancing expenses in the system and maintain high user satisfaction. Furthermore, from a global perspective, attention to electric vehicle charging stations in the bicycle station's location to help reduce greenhouse gas emissions and promote the use of more electric vehicles was not considered in previous studies. The construction of a bicycle station near a car charging station will help encourage citizens to use clean transportation. Therefore, it is suggested that the bicycle station's proximity to electric vehicle charging stations be considered a criterion in future studies. In addition, in a long-term plan, gas stations will devote all or part of their capacity to car and electric bicycle charging stations. The proximity of bicycle stations to current gas stations can be a practical suggestion.

- Main goals of previous studies

The main goal of most of the selected studies was finding the optimal station location, as is shown in Tables 1 and 2. The goal is usually pursued related to one of the domains of proposed categories in this study, or a combination. For example, in the "bike network" domain, the goal of the study by Guler and Yomralioglu [19] was to determine station locations and bicycle lanes together. In complementary work, the goal of Lin et al. [24] was finding the location of stations by considering the number of stations, bicycle lanes, and 
inventory levels at stations: concerning the operator perspective, the study considered the total cost and service levels. The impact of the initial budget allocated to the project on the station location was evaluated in [34]. User satisfaction, minimum walking distance between origin and stations, and user safety are the principal research goals for the user's perspective. In the domain of "city infrastructure", the more variable goals were considering the points of interest [29,38], public transport system [13,32], and providing access to the BSSs for low-income areas [34]. In general, in previous studies, while finding the optimal station location, if many and various sub-criteria were targeted in the study's goal, the study would be considered a more valuable study.

- Impact of city and BSS characteristics on station location

To plan a new BSS and expand a currently operated BSS, it must have comprehensive information about the city and BSS characteristics. City characteristics consist of its infrastructures, such as points of interest (schools, scenic area, parks, etc.), population and employment density [35], public transport system (proximity to bus stops, MRT stations, or LRT stations), topology (flat or uneven city), street network, and city size. There are very few studies that have considered most of these city characteristics in their location models. Instead, researchers often consider one or some of the city-related factors for simplicity of modeling. This procedure is quite similar for considering the BSS characteristics. Service densities include the number of bikes, racks in stations, and the number of stations in the system. In addition, to have an optimal location for stations, it is necessary to pay attention to the possibility of constructing bikeways and their integrity [19]. Although user transactions in a current operating system are essential in its expansion, a few studies [9,36] have used bike and racks usage data (whether empty or full station, respectively) in their research. In addition, demand prediction [34] can help operators to have a reasonable estimate of the number of future stations and, thus, perform correct management of the initial budget [10] by considering other operation concerns [36].

\subsection{Analysis of Location Techniques}

According to Tables 1 and 2, most studies added value in line with the applied location technique(s). Based on the available information, the systematization of the methods used for locating bicycle stations is one of the gaps observed in previous studies addressed in this paper. The location techniques are categorized into three proposed classifications, namely "mathematical algorithms", "multi-criteria decision making", and "GIS-based modeling".

GIS can utilize geographical aspects to create a spatial decision support system for solving complex planning problems by analyzing, editing, consulting, storing, and displaying spatial data. According to Tables 1 and 2, several techniques can be applied to improve the availability, efficiency, and responsiveness of BSSs. Within a complex spatial optimization context, GIS can support decision problems. In the studies related to planning and design problems (Table 1), six out of eleven studies used GIS-based modeling, four studies used a combination of GIS and MCDM, and two other studies combined GIS with a mathematical model. Therefore, more than $50 \%$ of the studies in planning and design problems have used GIS as one of the main pillars of their analytical technique. In the stage of operation improvement (Table 2), nine out of thirteen studies used GIS-based modeling: two studies used a combination of GIS and MCDM, two studies combined GIS with a mathematical model, one study used PPGIS platform, and four studies used GIS analysis (namely proximity analysis and geospatial analysis). Therefore, close to $70 \%$ of the studies have used GIS to solve operation improvement problems.

Figure 2 displays a conceptual diagram for the mixed use of the three techniques, highlighting the corresponding advantages that can be combined to excel station location problem resolution. Our review suggests that researchers pay more attention to GIS techniques and the high accuracy of this type of modeling. However, GIS potential will increase when combined with other methodological approaches. For example, one of the most widely used combined methods is GIS-based MCDM for spatial analysis and determining 
the best station location. GIS integration with MCDM brings their strengths together and can provide a more accurate analysis and a more robust decision for station location. Therefore, further use of GIS spatial analytical techniques combined with mathematical or MCDM methods is recommended for future studies in bike station locations. As an example, in a combined GIS/MCDM approach, the weights of criteria can be obtained using MCDM techniques, such as AHP, FAHP, ANP, or BWM. As for spatial data, the vector model is usually applied, enabling the enumeration of spatial features that facilitates the use of discrete models that MCDM techniques consider.

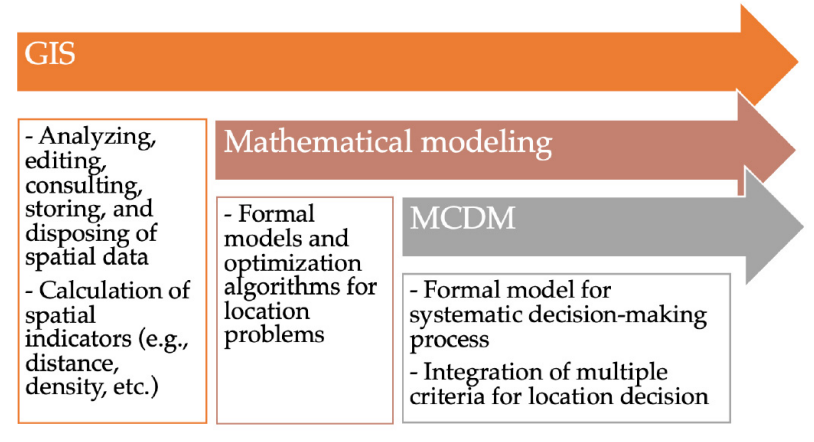

Figure 2. A conceptual diagram of the combination of techniques used for station location.

\section{Conclusions}

As the interest in promoting cycling through the implementation or expansion of BSSs continues to increase, it is crucial to address the planning problems related to the creation of stations in SBSSs and parking areas for the DBSSs. On the one hand, installing many service facilities such as stations in a system improves responsiveness to the demands and satisfaction of users, increasing the initial investment and operating cost. Therefore, optimized station location is an essential factor in designing and implementing a new BSS or in its expansion. The current review aims to identify the current state of practice for bike station location problems, station location criteria, and station location techniques.

Our principal contributions are:

- Classification of the two major problems: bicycle station location problems for initial network design, i.e., "Planning and Design", and changes in operating BSSs, i.e., "Operation Improvement".

- To the best of our knowledge, there is a lack of studies to identify, select, and collect data of applicable criteria for locating and classifying BSS stations. From the literature review analysis, we propose a classification of the main criteria for BSS station location according to four categories: "bike network", "operator", "user", and "city infrastructure". The sub-criteria mentioned in the literature were categorized based on the proposed classifications in Tables 3 and 4.

- Based on the available information, the systematization of the methods used for locating bicycle stations is one of the gaps observed in previous studies addressed in this review. The location techniques were categorized into three proposed classifications, namely "mathematical algorithms", "multi-criteria decision making", and "GIS-based modeling".

- GIS integration with MCDM brings their strengths together and can provide a more refined lens and a more accurate decision support tool for BSS station locations.

The creativity of using user locations and public questionnaires to receive station location suggestions were the two added values of recent studies concerning station location. The utilization of these two parameters is suggested in future studies. The results of this study can be beneficial for researchers, managers, and decision makers in both domains of designing a new BSS or developing an existing BSS in a city. 
Author Contributions: Conceptualization: Alexandre B. Gonçalves and Filipe Moura; Methodology: Mohammad Sadegh Bahadori, Alexandre B. Gonçalves, and Filipe Moura; Formal Analysis: Mohammad Sadegh Bahadori; Investigation: Mohammad Sadegh Bahadori; Writing-Review and Editing: Mohammad Sadegh Bahadori, Alexandre B. Gonçalves, and Filipe Moura; Supervision: Alexandre B. Gonçalves and Filipe Moura. All authors have read and agreed to the published version of the manuscript.

Funding: The first author was supported by Thales Group in Portugal, RPT-Thales, grant number: 4853.

Institutional Review Board Statement: Not applicable.

Informed Consent Statement: Not applicable.

Acknowledgments: The authors thank three anonymous reviewers whose comments have helped improve an earlier version of the paper.

Conflicts of Interest: The authors declare no conflict of interest.

\section{References}

1. Otero, I.; Nieuwenhuijsen, M.; Rojas-Rueda, D. Health impacts of bike sharing systems in Europe. Environ. Int. 2018, 115, 387-394. [CrossRef]

2. Cao, M.; Ma, S.; Huang, M.; Lü, G.; Chen, M. Effects of Free-Floating Shared Bicycles on Urban Public Transportation. ISPRS Int. J. Geo-Inf. 2019, 8, 323. [CrossRef]

3. Elliot, T.; McLaren, S.J.; Sims, R. Potential environmental impacts of electric bicycles replacing other transport modes in Wellington, New Zealand. Sustain. Prod. Consum. 2018, 16, 227-236. [CrossRef]

4. Marqués, R.; Hernandez-Herrador, V.; Calvo-Salazar, M.; García-Cebrián, J. How infrastructure can promote cycling in cities: Lessons from Seville. Res. Transp. Econ. 2015, 53, 31-44. [CrossRef]

5. Xiao, G.; Wang, R.; Zhang, C.; Ni, A. Demand prediction for a public bike sharing program based on spatio-temporal graph convolutional networks. Multimedia Tools Appl. 2021, 80, 22907-22925. [CrossRef]

6. Lusk, A.C.; Wen, X.; Zhou, L. Gender and used/preferred differences of bicycle routes, parking, intersection signals, and bicycle type: Professional middle class preferences in Hangzhou, China. J. Transp. Health 2014, 1, 124-133. [CrossRef]

7. Gutiérrez, J.G.; Romero-Torres, J.; Gaytan-Iniestra, J. Dimensioning of a Bike Sharing System (BSS): A Study Case in Nezahualcoyotl, Mexico. Procedia-Soc. Behav. Sci. 2014, 162, 253-262. [CrossRef]

8. Liu, J.; Sun, L.; Chen, W.; Xiong, H. Rebalancing Bike Sharing Systems. In Proceedings of the 22nd ACM SIGKDD International Conference on Knowledge Discovery and Data Mining, San Francisco, CA, USA, 13-17 August 2016; pp. $1005-1014$.

9. Garcia, D.A.E.; García, J.D.Z.; Velosa, C.Y. A GIS approach based on user location to evaluate a bike-sharing program. DYNA 2018, 85, 257-263. [CrossRef]

10. Frade, I.; Ribeiro, A. Bike-sharing stations: A maximal covering location approach. Transp. Res. Part A Policy Pract. 2015, 82, 216-227. [CrossRef]

11. Veillette, M.-P.; Grise, E.; El-Geneidy, A. Park ' $n$ ' Roll: Identifying and Prioritizing Locations for New Bicycle Parking in Québec City, Canada. Transp. Res. Rec. J. Transp. Res. Board 2018, 2672, 73-82. [CrossRef]

12. Çetinkaya, C. Bike Sharing Station Site Selection for Gaziantep. Sigma J. Eng. Nat. Sci. 2017, 35, 535-543.

13. Moshref Javadi, M.H.; Ghandehari, M.; Hamidi Pouyandeh, V. Locating of Bicycle Stations in the City of Isfahan Using Mathematical Programming and Multi-Criteria Decision-Making Techniques. Int. J. Acad. Res. Account. 2013, 3, 18-26. [CrossRef]

14. Yannis, G.; Kopsacheili, A.; Dragomanovits, A.; Petraki, V. State-of-the-art review on multi-criteria decision-making in the transport sector. J. Traffic Transp. Eng. 2020, 7, 413-431. [CrossRef]

15. Nadi, P.A.; Murad, A. Reviewing the use of Geographic Information System (GIS) to measure Sustainable Urban Transport performance. J. Geosci. Eng. Environ. Technol. 2017, 2, 171. [CrossRef]

16. Goodchild, M.F. GIS and Transportation: Status and Challenges. GeoInformatica 2000, 4, 127-139. [CrossRef]

17. Weber, A.; Friedrich, C.J. Theory of the Location of Industries; The University of Chicago Press: Chicago, IL, USA, 1929.

18. Hakimi, S.L. Optimum Locations of Switching Centers and the Absolute Centers and Medians of a Graph. Oper. Res. 1964, 12, 450-459. [CrossRef]

19. Guler, D.; Yomralioglu, T. Bicycle Station and Lane Location Selection Using Open Source GIS Technology. In Open Source Geospatial Science for Urban Studies; Springer: Cham, Switzerland, 2021; pp. 9-36. [CrossRef]

20. Fazio, M.; Giuffrida, N.; Le Pira, M.; Inturri, G.; Ignaccolo, M. Bike oriented development: Selecting locations for cycle stations through a spatial approach. Res. Transp. Bus. Manag. 2020, 100576. [CrossRef]

21. García-Palomares, J.C.; Gutiérrez, J.; Latorre, M. Optimizing the location of stations in bike-sharing programs: A GIS approach. Appl. Geogr. 2012, 35, 235-246. [CrossRef]

22. Chou, M.C.; Liu, Q.; Teo, C.-P.; Yeo, D. Models for Effective Deployment and Redistribution of Shared Bicycles with Location Choices. In Sharing Economy; Springer: Cham, Switzerland, 2019; pp. 409-434. [CrossRef] 
23. Wuerzer, T.; Mason, S.; Youngerman, R. Boise Bike Share Location Analysis. In Urban Studies and Community Development Faculty Publications and Presentations; School of Public Service, Boise State University: Boise, ID, USA, 2012; 13p, Available online: https:/ / scholarworks.boisestate.edu/planning_facpubs/8/ (accessed on 15 July 2021).

24. Lin, J.-R.; Yang, T.-H.; Chang, Y.-C. A hub location inventory model for bicycle sharing system design: Formulation and solution. Comput. Ind. Eng. 2013, 65, 77-86. [CrossRef]

25. Caggiani, L.; Colovic, A.; Ottomanelli, M. An equality-based model for bike-sharing stations location in bicycle-public transport multimodal mobility. Transp. Res. Part A Policy Pract. 2020, 140, 251-265. [CrossRef]

26. Mete, S.; Cil, Z.A.; Özceylan, E. Location and Coverage Analysis of Bike- Sharing Stations in University Campus. Bus. Syst. Res. J. 2018, 9, 80-95. [CrossRef]

27. Larsen, J.; Patterson, Z.; El-Geneidy, A. Build It. But Where? The Use of Geographic Information Systems in Identifying Locations for New Cycling Infrastructure. Int. J. Sustain. Transp. 2013, 7, 299-317. [CrossRef]

28. Kanjanakorn, T.; Piantanakulchai, M. Prioritizing Suitable Locations of Bike Sharing Station by Using the Analytic Hierarchy Process (AHP). In Proceedings of the International Symposium on the Analytic Hierarchy Process, Kuala Lumpur, Malaysia, 23-26 June 2013.

29. Kabak, M.; Erbaş, M.; Çetinkaya, C.; Özceylan, E. A GIS-based MCDM approach for the evaluation of bike-share stations. J. Clean. Prod. 2018, 201, 49-60. [CrossRef]

30. Banerjee, S.; Kabir, M.; Khadem, N.K.; Chavis, C. Optimal locations for bikeshare stations: A new GIS based spatial approach. Transp. Res. Interdiscip. Perspect. 2020, 4, 100101. [CrossRef]

31. Sun, Z.; Li, Y.; Zuo, Y. Optimizing the Location of Virtual Stations in Free-Floating Bike-Sharing Systems with the User Demand during Morning and Evening Rush Hours. J. Adv. Transp. 2019, 2019, 4308509. [CrossRef]

32. Shu, S.; Bian, Y.; Rong, J.; Xu, D. Determining the exact location of a public bicycle station-The optimal distance between the building entrance/exit and the station. PLoS ONE 2019, 14, e0212478. [CrossRef]

33. Askari, E.A.; Bashiri, M.; Tavakkoli-Moghaddam, R. A capacitated bike sharing location-allocation problem under demand uncertainty using sample average approximation: A greedy Genetic-Particle Swarm Optimization algorithm. Sci. Iran. 2017, 24, 2567-2580. [CrossRef]

34. Conrow, L.; Murray, A.T.; Fischer, H.A. An optimization approach for equitable bicycle share station siting. J. Transp. Geogr. 2018, 69, 163-170. [CrossRef]

35. Jin, B.; Hong, M.-H.; Lin, X.; Sha, J.-M. Service Sites Selection for Shared Bicycles Based on the Location Data of Mobikes. IEEE Access 2018, 6, 54965-54975. [CrossRef]

36. Wang, J.; Tsai, C.-H.; Lin, P.-C. Applying spatial-temporal analysis and retail location theory to public bikes site selection in Taipei. Transp. Res. Part A Policy Pract. 2016, 94, 45-61. [CrossRef]

37. Griffin, G.P.; Jiao, J. Crowdsourcing Bike Share Station Locations. J. Am. Plan. Assoc. 2019, 85, 35-48. [CrossRef]

38. Kurniadhini, F.; Roychansyah, M.S. The suitability level of bike-sharing station in Yogyakarta using SMCA technique. IOP Conf. Ser. Earth Environ. Sci. 2020, 451, 012033. [CrossRef]

39. Daskin, M.S. What you should know about location modeling. Nav. Res. Logist. 2008, 55, 283-294. [CrossRef]

40. Yang, S.; Yu, H.; Solvang, W.D. Location-Based Analysis and Optimization of Service Network Performance: A Case Study. In Proceedings of the 2018 2nd International Symposium on Small-scale Intelligent Manufacturing Systems (SIMS), Cavan, Ireland, 16-18 April 2018; pp. 1-6. [CrossRef] 